\title{
Population structure of Gyrinops versteegii within floristic community in Nggalak Protection Forest, Flores Island, Indonesia
}

\author{
ABBAN PUTRI FIQA`, SUGENG BUDIHARTA, FEBRINA ARTAULI SIAHAAN, RIDESTI RINDYASTUTI \\ Purwodadi Botanic Gardens, Research Center for Plant Conservation and Botanic Gardens, Indonesian Institute of Sciences. Jl. Raya Surabaya-Malang, \\ Km. 65, Purwodadi, Pasuruan 67163, East Java, Indonesia. Tel.: +62-343-615033, `email: abbanpf@gmail.com
}

Manuscript received: 10 February 2020. Revision accepted: 22 March 2020.

\begin{abstract}
Fiqa AP, Budiharta S, Siahaan FA, Rindyastuti R. 2020. Population structure of Gyrinops versteegii within floristic community in Nggalak Protection Forest, Flores Island, Indonesia. Biodiversitas 21: 1561-1568. Gyrinops versteegii (Gilg) Domke is one of the agarwood-producing plants native to eastern Indonesia with high level of exploitation in its natural habitat. Despite being protected by listing it in the CITES Appendix II, anecdotal evidence suggests that G. versteegii population continues to decline. Yet, there is limited empirical data to support such premise. This study was conducted to evaluate the abundance, population structure and floristic importance position of G.versteegii within vegetation community in its natural habitat in Nggalak Forest, Flores. Vegetation analysis was carried out at four growth stages: mature, immature, saplings, and seedlings stage. The results showed that G. versteegii was abundant in its natural habitat in Nggalak Forest in juvenile stages (i.e. seedlings to immature), but not in mature stage. Population densities for seedlings, saplings and immature stage were 313, 150 and 22 individuals per hectare respectively. G. versteegii also hold important position in the community structure, ranks $28^{\text {th }}, 6^{\text {th }}$, and $14^{\text {th }}$ for seedlings, saplings and immature stages respectively in term of importance value index. The high abundance and floristic importance of G. versteegii at the juvenile stages, but not at mature stages, indicates that rampant and over-exploitation of mature plants is likely the major threat to its population. We recommend to replicate similar study in other $G$. versteegii distribution areas. If similar pattern is found, conservation intervention in the form of protection of its natural population to sustain the juveniles to grow until mature stage may be required along with encouraging cultivation and reintroduction to enhance the population.
\end{abstract}

Keywords: Abundance, conservation, Gyrinopsversteegii, natural habitat, population structure

\section{INTRODUCTION}

Agarwood is a non-timber forest product (NTFP) in the form of resinous and aromatic wood as a result of tree being infected by particular fungal (FAO 2002). The tree species producing agarwood come from the genera Aquilaria, Gyrinops, and Gonystilus of the Thymeleaceae family which only grow in the tropics (Roemantyo and Partomihardjo 2010). However, only Aquilaria and Gyrinops have high economic value and are the most popular in the market, leading to a great demand for agarwood products yielded from these genera (Lee and Mohamed 2016). Agarwood is widely used for various purposes such as for religious rituals, aromatic and medicinal uses. Nowadays, agarwood demand in the form of chunks of wood, chips, powder, and oils remain high, particularly from Middle East and other Asian regions, with the best grade of agarwood may be traded at a price up to USD10,000/kg (Bardenet al. 2000).

Indonesia has the highest diversity of agarwood producing species among other Asian countries. One of them is Gyrinops versteegii (Gilg) Domke which is native to Papua, Sulawesi and Nusa Tenggara (Eastern Indonesia). This species is widely spread from the Lesser Sunda Islands, especially west Alor Island, Lombok Island and Flores Island to Sulawesi, Moluccas Islands and Papua (Roemantyo and Partomihardjo 2010; Susilo et al. 2014). G. versteegii is the most exploited agarwood species in its natural population in West Nusa Tenggara and East Nusa Tenggara Provinces. At present, the population of most agarwood producing trees including G.versteegii has decreased due to continuous harvesting without any significant population increase in its natural habitat (Roemantyo and Partomihardjo 2010; Rawana et al. 2018). In the 1970-1990 era, the increasing demand for agarwood had resulted in agarwood rush, resulting in a drastic decline in population (Katz 1997). The scarcity of agarwood supplies had caused sharp increase in its price, further triggering reckless harvesting practices that ignore sustainability aspects (Budiharta and Meijaard, in press).

The limited population of agarwood species in their natural habitat requires targeted conservation strategies. Differ with Aquilaria malaccensis which is increasingly popular in communities to be cultivated and developed into agarwood plantations, it is not the case for $G$. versteegii (Turjaman et al. 2016). Since 2005, G. versteegii has been included in Appendix II of CITES along with other species of agarwood in Indonesia with export quota restrictions up to 75 tons per year (Indonesian Ministry of Forestry 2001). CITES Appendix II contains a list of species that are not threatened to extinction, but maybe threatened to extinction if the trade continues unregulated.

Although $G$. versteegii has been listed in CITES Appendix II to limit and monitor its trade, the assessments of its conservation status according to the IUCN RedList criteria have not been carried out. This is likely caused by 
the lack of information required (e.g. geographical distribution, population, habitat and ecology, biological traits, fragmentation data, threats, etc.) when assessing its conservation status according to IUCN RedList criteria. This limited information results in less optimal attention and conservation efforts to reduce the threat of extinction in its natural habitat, for example by increasing its population through reintroduction programs. In addition, it is necessary to review the trade quota listed in the CITES Appendix based on scientific data and information regarding its population, especially in their natural habitat.

The investigation on population size and structures, geographical assessments, plant inventory and collection of rare and protected plant species are initial steps that are very important in making management decisions for its conservation. To assess its population in natural habitat, it is important to conduct field study combined with comprehensive review of the plant specimens (Pavlik 1997). Roemantyo and Partomihardjo (2010) stated that the population of $G$. versteegii was found in Manggarai and East Manggarai Districts, Flores Island at an altitude of 50$900 \mathrm{~m}$ asl. Preliminary study indicated that there was natural population of $G$. versteegii in the Nggalak protection forest, Manggarai District, Flores Island (Yulistyarini et al. 2019), yet a more detailed figure of $G$. versteegii population in this region is unknown. This study aimed to study the abundance, population structure and floristic importance of $G$. versteegii in its natural habitat in
Nggalak Protection Forest, Manggarai District, Flores Island. The results of this study can serve as baseline information for future research and management regarding the conservation of $G$. versteegii.

\section{MATERIALS AND METHODS}

\section{Study species and area of investigation}

Gyrinops versteegii is a small to large tree with height of 5-25 $\mathrm{m}$ and diameter up to $65 \mathrm{~cm}$ (Yulistyarini et al. 2019). It has oval-shaped leaves with $1.5-5 \mathrm{~cm}$ in width and $5-20 \mathrm{~cm}$ in length (Irsyad et al. 2020). Some individuals have relatively round leaves while others have tapered leaves with a wavy edge (undulate). The twigs of the round leaves usually have a brownish twig, and the tapered ones have a whitish twigs color. The leaf is bright green and shiny in the upper surface and dull green in the lower surface, it has 12-16 pairs of veins, and the base of the leaf is peg-shaped while the tip of the leaf is pointed out (Irsyad et al. 2020). The flowers have tube-shaped corolla, with 5 petals and 5 stamens (Yulistyarini et al. 2019). While it varies in terms of leaf morphology, it shares similarity in a particular character that distinguishes it from other agarwood species, i.e. the fruits might split themselves and separate each other when its ripening (dehiscent fruit) (Figure 1).

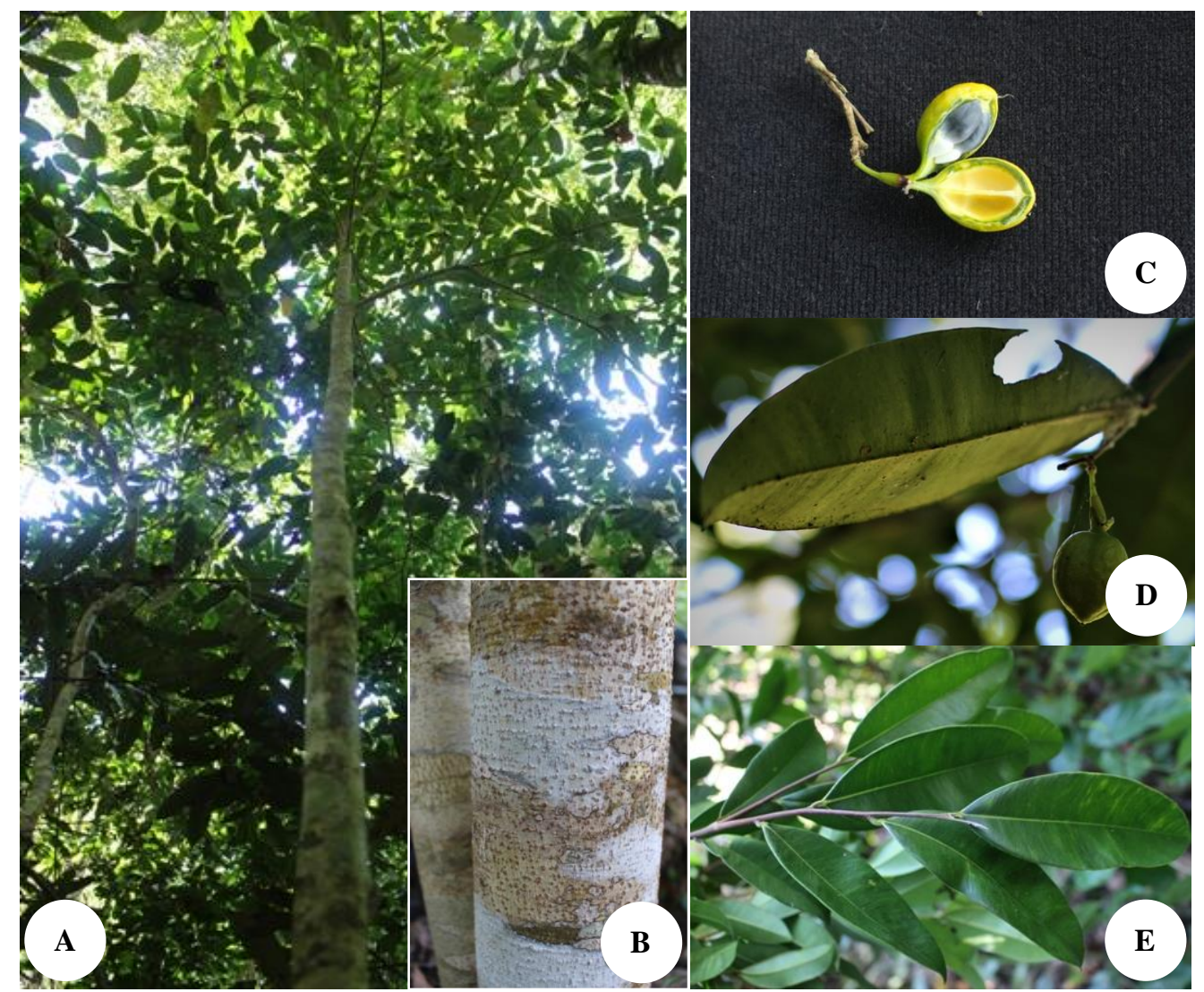

Figure 1. Morphological features of Gyrinops versteegii: A. Plant morphological form; B.. Trunk; C.. Dehiscent fruit when it is ripening, as the distinctive character between the genera of Gyrinops and Aquilaria; D.. Whole fruit; E.. Leaves 

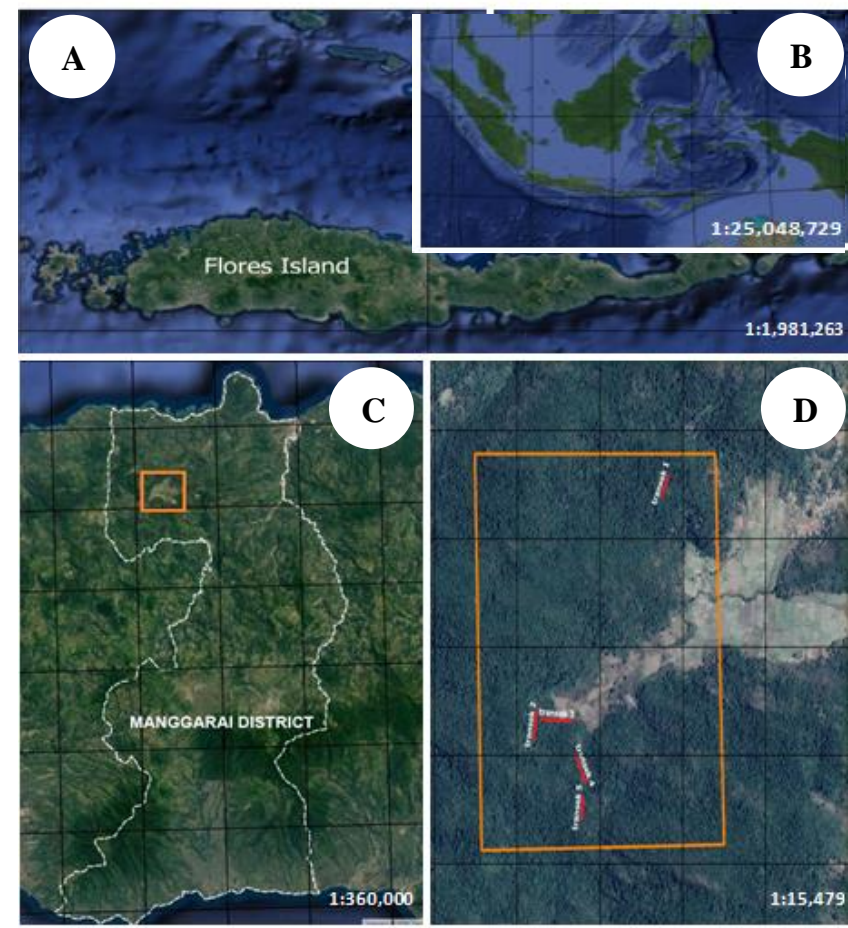

Figure 2. A. Indonesian region; B. Nggalak Protection Forest, West Reok sub-district, Manggarai District, Flores Island Study area as marked with a yellow square; C. Five observation transects located in the studied areas (Source: Google Earth, 2019)

The fieldwork was conducted from 22 July to 1 August 2018 in Nggalak Protection Forest (Hutan Lindung). Nggalak Forest is part of the Nggalak-Rego Forest Management Unit (Kesatuan Pengelolaan Hutan/KPH), which is administratively located in two districts, i.e. West Manggarai and Manggarai, and geographically is located in the northern part of Flores Island (Figure 2.A). This area is located at $08^{\circ} 36^{\prime} 075^{\prime \prime} \mathrm{S}-08^{\circ} 37^{\prime} 476^{\prime \prime} \mathrm{S}$ and $120^{\circ} 30^{\prime} 197^{\prime \prime} \mathrm{E}$ - 120 31'372" E with the altitude ranged between 484-604 $\mathrm{m}$ asl. The forest area has a variety of topography, from flat, sloping to steep with a type of soil consisting of limestone.

Nggalak Protection Forest has a total area of $825 \mathrm{Ha}$ and is one of several large and intact forests remaining in Flores Island. It was delineated in 1997 and assigned as state forest (Kawasan Hutan) under the authority of government with various changes in administration following the changes in bureaucratic reforms in central, provincial and district levels (East Nusa Tenggara Forestry Service, 2015). Currently, the forest area is classified as protection forest (hutan lindung) with the main aim to maintain the hydrological function in the nearby regions. Since it has been functioned as protection forest, logging is not allowed but harvesting not-timber forest products is permissible.

\section{Sampling procedures}

Vegetation analysis was carried out to determine the population structure of $G$. versteegii in its natural habitat in Nggalak Forest and its importance or level of dominance within the floristic community using the variables of Importance Value Index (IVI) and Shannon-Wiener
Diversity Index (Ludwig and Reynolds, 1988). Vegetation sampling was done using purposive random sampling by establishing five-line transects crossing the contour (Figure 2.B). Following the method by Kusmana (2007) with modification, each transect was established started from the point where a $G$. versteegii plant was found, then a straight line of transect with minimum length of $100 \mathrm{~m}$ was created. Along the transect, we made observation plots with size of $20 \times 20 \mathrm{~m}$ each plot in alternate configuration in the left and right of the transect with minimum number of five observation plots for each transect. There were 32 observation plots established, resulted in total extent of $12,800 \mathrm{~m}^{2}$. In each observation plot we set nested plots to record four growth stages, namely: seedling (vegetation with height $<1.5 \mathrm{~m}$ ) in $2 \times 2 \mathrm{~m}$ plot, sapling (diameter $<7$ $\mathrm{cm})$ in $5 \times 5 \mathrm{~m}$ plot, immature $(7 \mathrm{~cm}<$ diameter $<22 \mathrm{~cm})$ in 10 x $10 \mathrm{~m}$ plot, and mature (diameter $>23 \mathrm{~cm}$ ) in plot $20 \times 20 \mathrm{~m}$ plot. All plant species within the nested plots were identified and counted, the height of mature and immature plants was measured using hagameter, while the diameter of plant across the four stages was measured using tape measure. The identification was done by a specialist with experience of more than 30 years in botanical works.

Environmental data were also collected, including air temperature and humidity using thermo-hygrometer, altitude and latitude using GPS, and light intensity using luxmeter. In addition, soil samples in the depth of $0-20 \mathrm{~cm}$ were taken for further analysis of physical and chemical properties (i.e. soil texture, soil $\mathrm{pH}$, soil C-organic, soil total $\mathrm{N}$, soil organic matter, soil $\mathrm{P}$, and soil Cation Exchange Capacity/CEC) in the soil laboratory of Brawijaya University, Malang. 


\section{Data analysis}

The population structure of $G$. versteegii in its natural habitat was calculated based on the number of individuals per plot according to its vegetation stages (i.e. seedlings, saplings, immature and mature) and the values were extrapolated to result in population per hectare for each vegetation type. We also compared the population of $G$. versteegii with other plant species in the studied area.

To investigate the domination or the importance of $G$. versteegii within the floristic community, we calculated the Importance Value Index by adding the Relative Density (RD), Relative Frequency (RF), and Relative Coverage/Dominant (RC) (Soerianegara and Indrawan 2005). The three parameters were calculated as follows:

$$
\begin{aligned}
& \mathrm{RD}=\frac{\text { Number of individual of Species A }}{\text { Total number of individual }} \times 100 \\
& \mathrm{RF}=\frac{\text { Number of plot containing Species A }}{\text { Total frequencies of plant species }} \times 100 \\
& \mathrm{RC}=\frac{\text { Area coverage of Species A }}{\text { Total coverage in the area }} \times 100 \\
& \mathrm{IVI}=\mathrm{RD}+\mathrm{RF}+\mathrm{RC}
\end{aligned}
$$

The state of regeneration of $G$. versteegii its natural habitat was analyzed by the structure of population. In addition, the environmental factors were analyzed descriptively to relate them with $G$. versteegii population.

\section{RESULTS AND DISCUSSIONS}

\section{Environmental characteristics}

Nggalak Forest is located in the lowland area of West Reok sub-district, Manggarai District, about 484-603 m above sea level. In general, the average temperature and air humidity in Nggalak Forest area are $27.82^{\circ} \mathrm{C}$ and $73.8 \%$, respectively. In the forested area, light intensity is classified as low with an average of 804.8 lux, indicating a quite dense vegetation cover. The soil is classified as acidic with $\mathrm{pH}$ of less than 7 . The texture of the soil in this area is classified as clay. Percentage value of C-organic and soil organic matter is classified as high with organic $\mathrm{C}$-value and organic matter respectively $4.09 \%$ and $7.08 \%$. The total $\mathrm{N}$ value is $0.39 \%$, which is classified as moderate, while the $\mathrm{C} / \mathrm{N}$ and $\mathrm{P}$ values are classified as low, which are 10.3 and $5.03 \mathrm{ppm}$. The value of soil CEC in the Nggalak forest is classified as very high at 51.92/100 grams of soil.
Nggalak forest is classified as secondary forest with quite good soil fertility.

\section{Population structure of Gyrinops versteegii}

There are only three stages of $G$. versteegii found at the studied areas in Nggalak Forest, including seedling, sapling, and immature stages with no mature stage are recorded (Table 1 and Figure 3). Individual with the largest diameter in the population is about $10.83 \mathrm{~cm}$, while the highest plant in the population is $12 \mathrm{~m}$. The largest diameter and the highest individuals are both at the immature stage.

In general, the population of G.versteegii in the Nggalak Forest area is quite abundant but the number of individuals decreases with the increasing stage of growth. The population at seedling stage is doubled when compared to the sapling stage, whereas in the immature stage the number is only $15 \%$ when compared to the sapling stage. The number of $G$. versteegii at seedling, sapling and immature stages is 313,150 and 22, respectively, while the mature stage is absent (Figure 3).

The population of $G$. versteegii in Nggalak Protection Forest was further investigated by comparing it to other species. Overall, compared to other species, the population density of $G$. versteegii is quite low. At the seedling stage, the number of individuals per hectare of $G$. versteegii is only $2.18 \%$, while Aglaia tomentosa with population density 14.375 individuals/ hectare, and is noted as the species with the highest density (Figure 4.A). At the sapling stage, the population density of $G$. versteegii is almost half of that of Syzygium racemosum, which is the species with the highest density (Figure 4.B). Again at the immature/ pole stage, $S$. racemosum is the species with the highest density which is three times the density of $G$. versteegii (Figure 4.C).

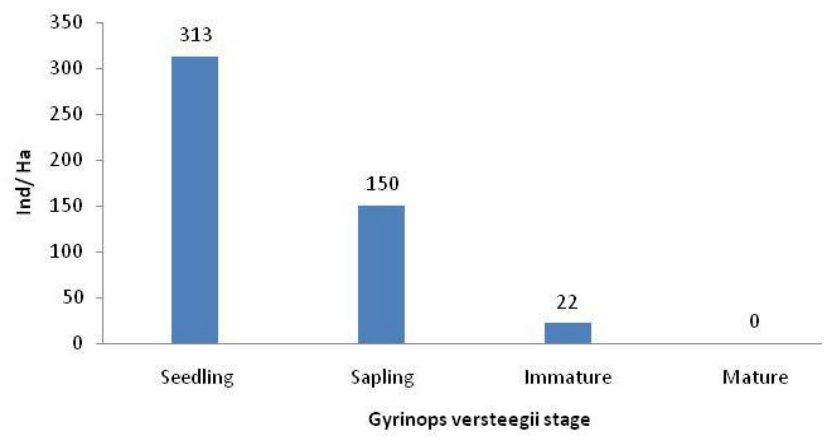

Figure 3. The population structure of Gyrinops versteegii (in individual per hectare at each growth stage) in Nggalak Protection Forest, Manggarai District, Flores Island.

Table 1. The population structure of Gyrinops versteegii at each growth stage in Nggalak Protection Forest, Manggarai District, Flores Island, East Nusa Tenggara, Indonesia

\begin{tabular}{lcccc}
\hline \multicolumn{1}{c}{ Stage } & Average diameter $(\mathbf{c m})$ & Maximum diameter $(\mathbf{c m})$ & Average height $(\mathbf{m})$ & Maximum height $(\mathbf{m})$ \\
\hline Mature & 0 & 0 & 0 & 0 \\
Immature & $8.69 \pm 1.55$ & 10.83 & $8 \pm 3.16$ & 12 \\
Saplings & $3.98 \pm 1.49$ & 6.69 & $3.06 \pm 1.84$ & 5.5 \\
Seedlings & $1.06 \pm 0.95$ & 3 & $1.75 \pm 0.31$ & 1.5 \\
\hline
\end{tabular}




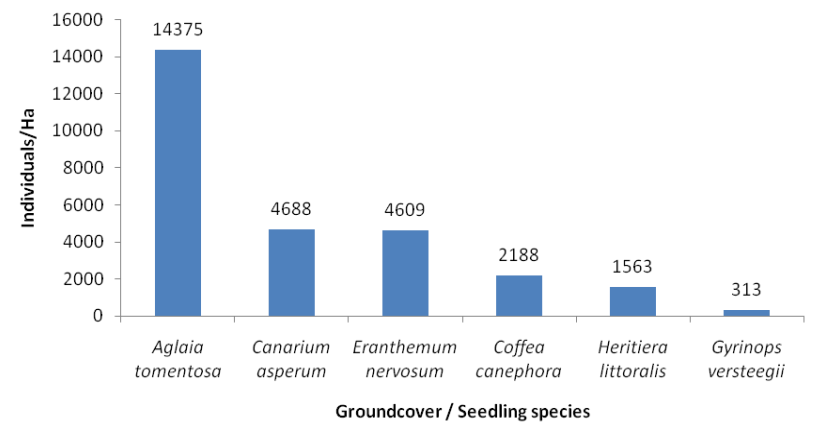

A
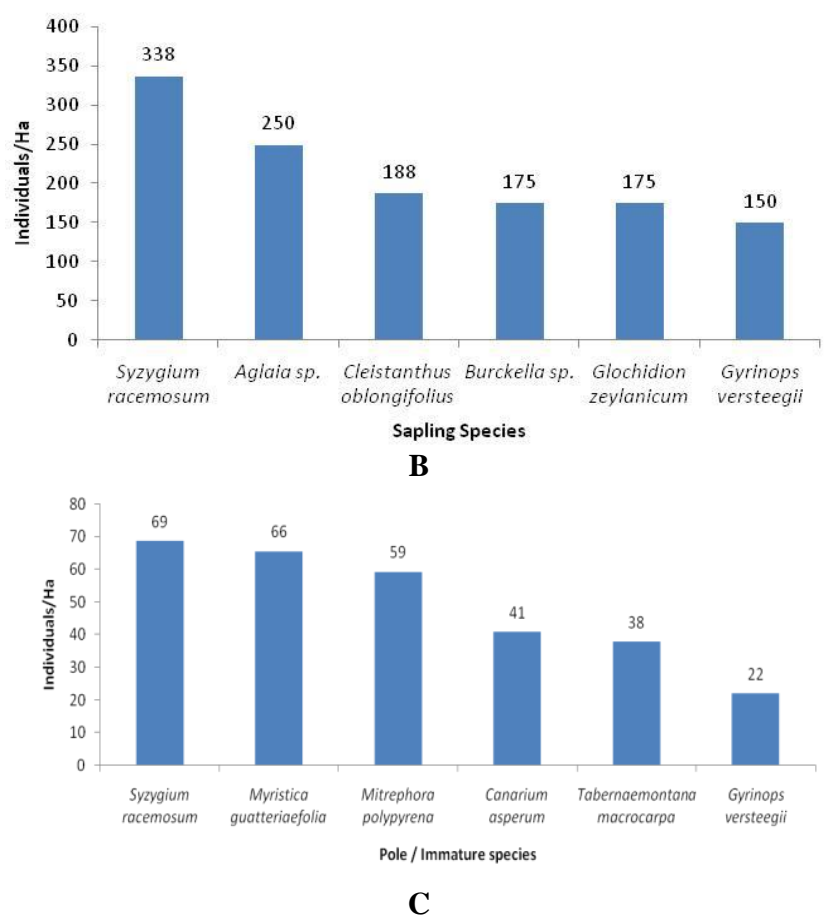

Figure 4. The population of Gyrinops versteegii compared to other species at each growth stage in Nggalak Protection Forest, Manggarai District, Flores Island, Indonesia. A. seedling; B. sapling; and C. immature/pole.

\section{The importance of Gyrinops versteegii within floristic community in Nggalak Protection Forest}

The floristic importance of $G$. versteegii within floristic community was analyzed based on the Importance Value Index (IVI) compared to other species within the vegetation community (Figure 5). Importance value reflects relative contribution of a species to the entire vegetation community. Importance Value Index (IVI) was obtained as the sum of three ecological variables namely Relative Density (RD), Relative Frequency (RF) and Relative Coverage/Dominant (RC).

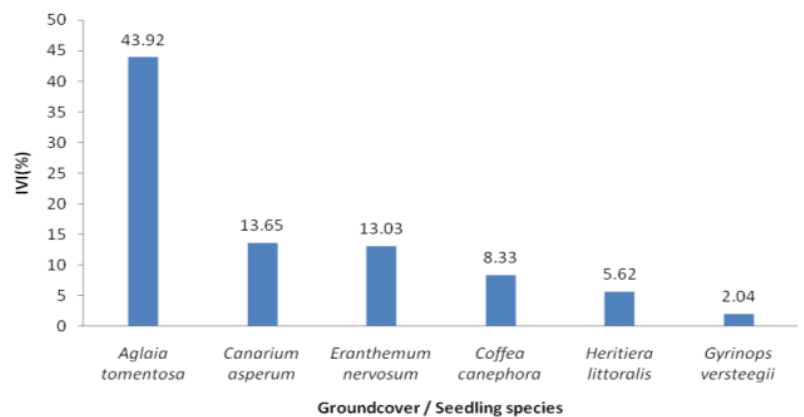

A
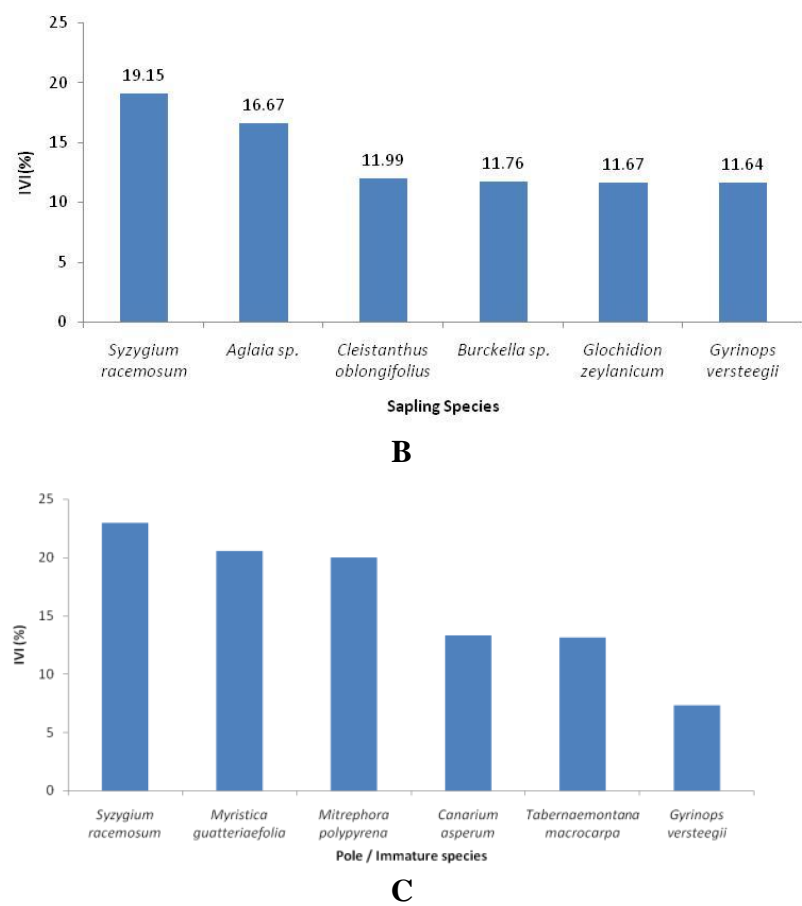

Figure 5. The Importance Value Index (IVI) of Gyrinops versteegii compared to the five plant species with the highest IVI at different growth stages. A. seedlings/ groundcover; B. saplings; C. immature/pole.

At seedling stage, $G$. versteegii ranks $28^{\text {th }}$ out of a total of 80 species across all observation plots with an IVI value of $2.04 \%$ (Figure 5.A). At this growth stage, the highest value is held by Aglaia tomentosa which over dominates the groundcover with an IVI value of $43.92 \%$. Differ with seedling stage; community structure at the sapling stage is more balanced with the absence of dominating plant species, where the highest IVI value is showed by Syzygium racemosum with $19.15 \%$ (Figure 5.B). At the sapling stage, $G$. versteegii ranks $6^{\text {th }}$ with IVI value of $11.64 \%$, suggesting that this species is able to compete within the community structure and hold an important role in composing the vegetation. Whereas at the immature/ pole stage, $G$. versteegii ranks $14^{\text {th }}$ with an IVI value of $7.31 \%$, while the highest IVI value is also possessed by $S$. racemosum (Figure 5.C). 
Table 2. The comparison of population density of Gyrinops versteegii (ind/Ha) in natural habitats in several areas in East Nusa Tenggara Province, Indonesia

\begin{tabular}{lcccc}
\multicolumn{1}{c}{ Natural habitat } & Seedling & Saplings & Immature & Mature \\
\hline Nggalak Protection Forest & 313 & 150 & 22 & 0 \\
Pongkor Community Forest (Rindyastuti et al. 2019) & 23 & 15 & 4 & 6 \\
Mt. Timau (Sujatmoko et al. 2011) & 117 & 674 & 5 & 0 \\
\hline
\end{tabular}

\section{Discussions}

Population structure and floristic importance of Gyrinops versteegii

Based on the field study carried out in Nggalak Protection Forest, West Reoksub-district, Manggarai District, Flores G. versteegii population is only found at juvenile stages (i.e. seedling, sapling, and immature). Of the 32 observations plots, there is no $G$. versteegii at mature stage. The analysis of population structure shows that there is relatively large population at the seedling, sapling and immature stages. In addition, $G$. versteegii plays important role in composing the vegetation especially at the sapling and pole stages indicated by the relatively high IVI and species ranks.

The absence of $G$. versteegii at the mature stage is presumably caused by over-exploitation by hunters, collectors, traders, or local communities. This presumption is strengthened by the statements of several guides that according to the story of their elders there were still many G. versteegii trees at large size in the Nggalak Forest about two or three decades ago. The absence of $G$. versteegii at mature stage in our study is similar with the study by Sujatmoko et al. (2011) which found there is no $G$. versteegii at mature stage in natural forest at Mt. Timau, Amfoang, Timor Island, East Nusa Tenggara Province (Table 2). They stated that massive exploitation in Amfoang was occurred in 1990 by the companies that received permission from Indonesian government. At the end of company exploitation period, at 1994, local people started to search for the remnants of $G$. versteegii. However, the low understanding of the local people about the plant caused exploitation even to the level of immature and sapling (Sujatmoko et al. 2011).In contrast, different result is showed by Rindyastuti et al. (2019), which found several trees of $G$. versteegii at a small fragmented forest area in Pongkor, Manggarai District, Flores Island (Table 2 ). The existence of $G$. versteegii at mature stage in the community forest area of Pongkor is likely due to community monitoring which might be done intensively, moreover, the Pongkor forest area is relatively smaller when compared to the forest area both in Nggalak and Amfoang. All these results combined with statements by local guides suggest that in Flores Island in some large extent forest areas with dense vegetation cover and deeper inside, the exploitation of mature plants by collectors likely still occurs.

Despite the absence of $G$. versteegii at mature stage, the high number of juveniles in Nggalak Forest indicates that this species is likely able to survive in its natural habitat because it provides new plant generations for species existence. The relatively abundant of individuals at juvenile stages might also relate to the seed biological traits (e.g. seed germination, whether the seed is orthodox or recalcitrant, etc.) and seed dispersal pattern. While information regarding seed biological traits is lacking, a recent study indicates that the dispersion pattern of $G$. versteegii metapopulation tends to be clumped or uniform, although it is not clear what the underlying background for these patterns (Yulistyarini et al. submitted). Further researches on regeneration and dispersal issues are therefore required.

The high number of seedlings also indicates that this species is possible to be developed as a commodity traded on a large scale in the future. The population structure of G. versteegii in this forest can be classified to have "good regeneration" based on the ecological principles of forest structure, because it has the structure of seedling > sapling $>$ adult (Paul et al. 2019). The population structure of $G$. versteegii in Nggalak Forest is quite different and better in terms of plant regeneration compared to the structure in Pongkor, Flores that showed higher sapling stage than the seedling stage (Rindyastuti et al. 2019).

Within the vegetation community in Nggalak Forest, the rank of IVI of $G$. versteegii could be classified as moderate compared to previous study by Rindyastuti et al. (2019). The IVI and rank are not the highest, however, it is quite high for a high exploited-rare species. A recent study also shows that this species is tolerant in a broad range of canopy cover and light intensity across growth stages (Yulistyarini et al. submitted), suggesting that shading is not the constraint in recruitment pattern. This evidence suggest that $G$. versteegii is actually able to regenerate, survive and compete within vegetation community in its natural habitat. This premise is supported by the fact that in Nggalak Forest, $G$. versteegii ranks $28^{\text {th }}$ at the seedling stage, and ranks $6^{\text {th }}$ at the sapling stage, indicating a high survival rate relative to the other species during the juvenile stages. However, at the immature stage, it turns to rank $14^{\text {th }}$. Our personal observation found some cases of immature plants being destructed by human, leaving them into stumps. This is in accordance with the finding by Sujatmoko et al. (2011) that destructive agarwood harvesting at Gunung Timau, Amfoang, Timor Island, East Nusa Tenggara could occur at younger stages.

Besides threatening the population of a species per se, destructive harvesting will affect the structure and composition of natural forest, either directly or non-directly (Edwards et al. 2019). This activity will also cause a problem on soil humidity and nutrient loss, moreover, open canopy will also support the growth of invasive species 
(Addo-Fordjour et al. 2009; Riggert et al. 2017). Destructive harvesting of $G$. versteegii especially at the mature stage, will disrupt the regeneration of this species, since tree individuals are more productive than younger individuals in case of seed production.

\section{Implication for species conservation}

Naturally, G. versteegii requires lower light intensity which can be obtained from natural forest habitats and is considered as a shading tolerant species (Mulyaningsih et al. 2017), although a recent study found this species is able to grow in relatively open area (Yulistyarini et al. submitted). The intact forest with natural and climax vegetation could maintain the population size, growth and reproductive biology of plant species ecologically (Gibson et al. 2011). Therefore, the forest of Nggalak can be considered as suitable for the conservation of $G$. versteegii in its natural habitats, especially in Flores Island.

To maintain the population of rare and protected species, there should be an effort to increase population size in their natural habitats, for example through reintroduction program, because the population size affects to plant reproductive output (Komar et al. 2014). Fortunately, a very high number of seedling in Nggalak Protection Forest suggests that the population of $G$. versteegii has high regeneration level. However, to protect its existence in the natural habitat, government should still pay attention to the seedling stage, since seedling is also exploited by the local people for cultivation activities (Sujatmoko et al. 2011). The improvement of population size in its natural habitat could be encouraged by controlling the growth of plant in seedling stage to the bigger plant size. This is because the natural populations of $G$. versteegii in Flores are proven to have high genetic variation, which is very important for species conservation (Irsyad et al. 2020).

Apart from protecting the natural population of $G$. versteegii in its natural habitat such as in Nggalak Forest, another conservation effort through population enrichment might be required. This can be done by conducting propagation and cultivation program using agroforestry system to increase the population of Gyrinops versteegii outside its natural habitats. Agroforestry, as a form of land use management, is regarded to be able to contribute to solve both on environmental problems and also the community interests (Parotta et al. 2015). The cultivation of $G$. versteegii on agroforestry lands has been widely practiced, both on its original distribution areas, such as in East Nusa Tenggara, as well as in other areas such as West Java, Central Java, East Java, Bali, West Kalimantan, East Kalimantan, West Nusa Tenggara, Gorontalo, and Papua (Turjaman and Hidayat 2017; Rawana et al. 2018). G. versteegii tends to be tolerant to living outside its natural distribution area, however, it has a special requirement to grow well, i.e. growing in areas with diverse vegetation that have interrelationship with each other (Rawana et al. 2018). Due to its high economic value, the community is very interested in developing this species as agarwood producing tree, despite the fact that the development of agroforestry is always constrained by the need for large tracts of land (Kurniawan and Pujiono 2018).

The population enrichments of $G$. versteegii through cultivation might require the supports of ex-situ conservation efforts carried out by botanic gardens in order to maintain genetic diversity (Pavlik 1997). Also, to maintain the genetic variation, the cultivation needs to be conducted using plant generative organs (i.e. seeds) and not using soma-clonal propagation techniques such as tissue cultures and vegetative propagations. This is because the offspring, as the results of plant propagation, could obtain new regeneration of agarwood producing trees with high species fitness, resistance to diseases and uncertain environmental changes (Allendorf and Luikart 2007; Frankham et al. 2002; Szczecińska et al. 2016).

On a national scale, the conservation of $G$. versteegii could also be supported by regulating the harvesting of mature plants growing naturally in forest areas. If similar results of this study (i.e. the absence of mature population) also occur in other areas, enacting stricter quota might be required than currently stated (i.e. 75 tons per year). If urgently needed, a moratorium of trade on agarwood products produced by G.versteegii might be required for a certain period as applied to ramin (Gonystylus bancanus) (Barstow 2018). Therefore, we recommend that similar study can be conducted in other regions to see whether similar trend happens.

\section{ACKNOWLEDGEMENTS}

The study of the population of Gyrinopsversteegii in Flores Island could be carried out by the research funding from the DIPA of the Research Center for Biology-LIPI through the CITES program year 2018. Our gratitude also goes to the NTT Province BBKSDA and the Manggarai District Forestry Service, Flores, East Nusa Tenggara for giving permission to enter and conduct research in forest area. The authors also thank Adolfus Ria (Manggarai District Forestry Service, Indonesia) for his trip assistance, Matrani and Dahlan (the staff of Purwodadi Botanic Gardens, Pasuruan, Indonesia) for their technical supports during the field study. $\mathrm{ABF}$ and $\mathrm{SB}$ are the main contributors to this paper.

\section{REFERENCES}

Addo-Fordjour P, Obeng S, Anning AK, Addo MG. 2009. Floristic composition, structure and natural regeneration in a moist semideciduous forest following anthropogenic disturbances and plant invasion. Intl J Biodivers Conserv 1 (2): 021-037.

Allendorf FW, Luikart GH. 2007. Conservation and the Genetics of Population. Blackwell Publishing, Victoria.

Barden A, Anak AN, Mulliken T, Song M. 2000. Heart of the Matter: Agarwood Use and Trade, and CITES implementation for Aquilaria malaccensis. TRAFFIC International, Cambridge, UK.

Barstow M. 2018. Gonystylus bancanus. The IUCN Red List of Threatened Species 2018: e.T32941A68084993. DOI: 10.2305/IUCN.UK.2018-1.RLTS.T32941A68084993.en.

Downloaded on 21 August 2018.

Budiharta S, Meijaard E. in press. State of Kalimantan's biodiversity. In: Resosudarmo BP, Imansyah MH, Napitupulu L (eds.). Development, 
Environment and the People of Kalimantan. Indonesian Regional Science Association, Jakarta.

East Nusa Tenggara Forestry Service. 2015. Long term forest management plan of Manggarai Forest Management Unit. East Nusa Tenggara Forestry Service, East Nusa Tenggara.

Edwards DP, Socolar JB, Mills SC, Burivalova Z, Koh LP, Wilcove DS. 2019. Conservation of Tropical Forests in the Anthropocene. Curr Biol 29: R1008-R1020.

Gibson L, Lee TM, Koh LP, Brook BW, Gardner, TA, Barlow J, Peres CA, Bradshaw CJA, Laurance WF, Lovejoy TE, Sodhi NS. 2011 Primary forests are irreplaceable for sustaining tropical biodiversity. Nature 478: 378-381.

Irsyad AF, Rindyastuti R, Yulistyarini T, Darmayanti AS, Daryono BS. 2020. Genetic variation of agarwood producing tree (Gyrinops versteegii) from Pongkor, Manggarai District, Flores Island, Indonesia using ISSR molecular markers. Biodiversitas 21: 485-491.

Katz E. 1997. NWFPs in Bulungan, East Kalimantan, Indonesia. In:

Mittelman AJ, Lai CK, Byron RN, Michon G, Katz E. 1997. Non wood forest product outlook study for Asia and the Pacific: towards 2010. Asia-Pacific Forestry Sector Outlook Study Working Paper No. APFSOS/WP/28. FAO. Forestry Policy and Planning Division and Regional Office for Asia and the Pacific, Rome, Italy.

Indonesian Ministry of Forestry. 2001. Kuota EksporJenis-jenis Gaharu. www.menlhk.go.id. [Indonesian]

Komar TE, Wardani M, Hardjanti FI, Ramdhania N. 2014. In-situ and Exsitu Conservation of Aquilaria and Gyrinops: A Review. IPB Press, Bogor.

Kurniawan H, Pujiono E. 2018. Potential for development of local original plants in agroforestry systems: Case study in T'eba village Timor Tengah Utara District, East Nusa Tenggara. Jurnal Faloak 2 (2): 71-88 [Indonesian]

Kusmana C. 2007. Metode Survey Vegetasi. PT. Penerbit Institut Pertanian Bogor, Bogor, Indonesia. [Indonesian]

Lee SY, Mohamed R. 2016. The origin and domestication of Aquilaria, an important Agarwood-producing Genus. In: Mohamed R (ed.) Agarwood Science behind the Fragrance. Springer, Singapore

Ludwig JA, Reynolds JF. 1988. Statistical Ecology A Primer on Methods and Computing. Wiley-Interscience Pub, New York.

Mulyaningsih T, Marsono D, Sumardi, Yamada I. 2017. The presence of eaglewood Gyrinopsversteegiiin the natural forest of West Lombok Island, Indonesia. Ecol Environ Conserv 23 (2): 723-729.

Parotta JA, de Pryck JD, Obiri BD, Padoch C, Powell B, Sandbrook C, Agarwal B, Ickowitz A, Jeary K, Serban A, Sunderland TCH, Tran NT. 2015. The Historical, Environmental and Socio-Economic Context of Forests and Tree-Based Systems for Food Security and Nutrition. International Union of Forest Research Organizations (IUFRO), Vienna, Austria.
Paul A, Khan ML, Das AK. 2019. Population structure and regeneration status of rhododendrons in temperate mixed broad-leaved forests of western Arunachal Pradesh, India. Geol Ecol Landscap 3: 168-186.

Pavlik BM. 1997. Perspectives, tools, and institutions for conserving rare plants. Southwestern Nat 42 (4): 375-383.

Rawana, Hardiwinoto S, Budiadi, Rahayu S. 2018. Vegetation community and environment on Gyrinops versteegii growth. Jurnal Manajemen Hutan Tropika 23 (1): 10-22. [Indonesian]

Riggert R, Fleige H, Kietz B, Gaertig T, Horn R. 2017. Dynamic stress measurements and the impact of timber harvesting on physical soil properties. Austr For 80: 255-263.

Rindyastuti R, Yulistyarini T, DarmayantiAS. 2019. Population and ecological study of agarwood producing tree (Gyrinops versteegii) in Manggarai District, Flores Island, Indonesia. Biodiversitas 20 (4): 1180-1191.

Roemantyo, Partomihardjo T. 2010. Analysis of prediction of the natural distribution of agarwood Genus Aquilaria and Gyrinops in Indonesia. Berita Biologi 10 (2): 189-205.

Sujatmoko S, Soenarno, Siswadi, Prasetyo BD. 2011. Utilization and condition of agarwood producing tree populations in NTT. Paper on "Gelar Teknologi Hasil Penelitian" Science and Technology for the Welfare of the People of West Sumba, Waikabubak. [Indonesian]

Susilo A, Kalima T, Santoso E. 2014. Field Guide of Agarwood Producing Trees Gyrinops spp. Introduction in Indonesia. Research and Development Center of Conservation and Rehabilitation. Forestry Ministry of Indonesia, Bogor. [Indonesian].

Szczecińska M, Sramko G, Wołosz K, Sawicki J. 2016. Genetic diversity and population structure of the rare and endangered plant species Pulsatilla patens (L.) Mill in East Central Europe. PLoS ONE 11 (3): e0151730. DOI: 10.1371/journal. pone.0151730.

Turjaman M, Hidayat A, Santoso E. 2016. Development of agarwood induction technology using endophytic fungi. In: Mohammed R (eds). Agarwood, Science behind the Fragrance. Springer Science Bussiness Media, Singapore.

Turjaman M, Hidayat A. 2017. Agarwood-planted tree inventory in Indonesia. IOP Conf Ser Earth Environ Sci 54: 012062. DOI: 10.1088/1755-1315/54/1/012062

Yulistyarini T, Rindyastuti R, Darmayanti AS, Budiharta S, Fiqa AP, Siahaan FA. 2019. Study of habitat and morphological variation of agarwood (Gyrinops versteegii (Gilg) Domke) in Manggarai Regency, Flores. Proceeding of National Conference "Conservation dan Utilization of Wild Plant and Animal, Research Center for Biology, LIPI, Bogor. [Indonesian]

Yulistyarini T, Fiqa AP, Budiharta S, Rindyastuti R. submitted. Distribution of Gyrinops versteegii (Gilg.) Domke in varying vegetation structures, soil properties, and microclimates in Flores Island, Indonesia. 